\title{
The Czech Republic and the Reality of Migrant Integration Policy in the Context of European Integration
}

\author{
Helena Bauerová* \\ UDK $\quad 341.43: 352(437.1)$ \\ $351.756(437.1)$ \\ 341.43:341.176(4)EU \\ 339.923:061.1(437.1:4EU) \\ DOI \\ 10.31297/hkju.18.3.3 \\ Review scientific paper / pregledni znanstveni rad \\ Received / primljeno: 16.7.2018. \\ Accepted / prihvaćeno: 18.4.2018.
}

The Czech Republic, in the context of its accession to the $\mathrm{EU}$ and subsequently as a full-fledged EU member state, has been undergoing the process of Europeanisation in the field of migration and integration policy. The article focuses on and classifies the character of integration (and partially migration) policy. The paper's main claim is that the Czech Republic has mitigated its restrictive approach to migration and integration policy because of its accession to the EU, specifically by harmonising Czech legislation with European law. The migration crisis has accelerated updates and changes to the Czech integration policy, which are at odds with Europeanisation. The paper analyses the

Helena Bauerová, PhD, Department of International Relations and European Studies, Metropolitan University Prague, Head of MUP University Centre in Pilsen, Czech Republic (Odsjek za međunarodne odnose i europske studije, Metropolitan Sveučilište u Pragu, voditeljica Sveučilišnog centra u Pilsenu, Češka, e-mail: helena.bauerova@mup.cz)

ORCID ID: https://orcid.org/0000-0003-2220-5026. 
main problems of integration policy at the central and local level in the context of Europeanisation. The analysis covers the period between 1993 and 2015 in order to demonstrate whether migration and integration policy has been functional or not.

Keywords: Czech Republic, migration policy, integration policy, Europeanisation, migration crisis

\section{Introduction ${ }^{1}$}

For a long time, the Czech Republic (CR) was not forced to solve problems of migrant integration and associated phenomena precisely because of its transit character. Migration and integration policy came to the fore in political decisions and social discourse in the context of the migration crisis. Because of the activities that the CR performs with regard to migrants at the state, local, and EU level, this paper attempts to analyse migration and integration policy, especially towards migrants in the CR.

We believe integration policy towards migrants to be affected by two principal factors: a) the CR is a small transit country without an external Schengen border, and b) historical experience (especially the country's communist past) supports a very restrictive attitude towards migrants, which is subsequently reflected in integration policies towards migrants and the attitudes of civil society. The character of integration policy should be classified with regard to rules for granting citizenship. The paper's main claim is that the CR has mitigated its restrictive migration and integration policy because of its accession to the $\mathrm{EU}$, and has done so by harmonising Czech legislation with European law. In this context, the CR has reformed its migration policy rather than integration policies towards migrants. The CR used an individual-based approach to migrants in its integration policy. However, the current migration situation in Europe has forced the CR to become more active and to refine the rules governing the integration of immigrants at the local level. The hypothesis of the paper is that the migration crisis has accelerated updates and changes to the integration policy in the CR, while at the local level changes have

1 This paper is the result of Metropolitan University Prague Research Project No. 5702 "Territorial Studies, Economics, International Relations" (2017), based on a grant from the Institutional Fund for the Long-Term Strategic Development of Research Organisations. 
not been observed to work in practice (this paper would like to identify the main problems). In the long term, it is necessary to take into account social resistance, historical traditions, and cultural assimilation as indispensable elements of migrant integration. Integration policies aimed at migrants fail mainly because primary activities are realised by the central authorities of the CR; the local level is passive or simply performs its assigned tasks. Non-profit organisations are the most active participants in the integration policy and perform the activities of local actors in many respects. From a chronological viewpoint, the analysis will cover the period 1993-2015 and demonstrate whether the migrant integration policy has been functional or not. The analysis will be conducted at three levels: local, national, and that of the EU. The theoretical tool is the Europeanisation theory, which can explain the extent to which European law is implemented at the state level, as well as in subnational units. This theory helps verify the second hypothesis; i.e., the CR has implemented a more active integration policy because the huge migration wave was interpreted as a potential danger rather than because of the pressure of European law.

\section{Europeanisation}

The theory of Europeanisation is dynamic theoretical concept, which is very popular in the CR and a range of other countries (Cabada \& Hloušek, 2009; Hloušek \& Pitrová, 2009; Radaelli, 2003; Schmidt \& Radaelli, 2004). This concept, which is actively used by political science and other social sciences, defines the relationship between the European Union (EU) and the political systems of EU member states (at all levels: policy, politics, and polity). It may be said that many analyses has focused on expressions of Europeanisation in member states, predominantly after the biggest enlargement in a relatively short period of time. There has been intensive research on the topic of Europeanisation but it is impossible to arrive at a clear consensus on how this concept may be perceived. In this paper Europeanisation is seen as a two-way process (both top-down and bottom-up) (Fink-Hafner \& Lajh, 2003, p. 19; Hloušek \& Pitrová, 2009, p. 35). Europeanisation is a) the expression of pressure from the EU, which leads to a change in the behaviour of actors at the state level and lower sub-state units (see Börzel, 2005) and b) pressure which comes from the state as a unit that does not accept Europeanisation automatically or smoothly. The state may either be an active participant that has adapted to the process of Europeanisation or it is reluctant to accept its effects. 
Europeanisation will be seen as a process, a notional place of impact of national or social interests, and as the pressure of the EU to transmit European values. The process of interaction does not always lead to a consensus between European interests and the interests of member states. Two specific areas (the EU area and state area) meet and become connected in the process of Europeanisation. It is possible to talk about areas of overlapping interests of different character. This paper concentrates mostly on the area of polity. The polity analysis will be studied in relation to political institutions and their adaptation and transformation with regard to Europeanisation. Institutional changes under the pressure of Europeanisation will be analysed.

\section{Migration and Integration Policy of the Czech Republic}

Czech migration policy has undergone a long evolution. Until the end of the 1980s migration and integration policies were influenced by communism and it is impossible to say that these two policies were developed democratically and openly. ${ }^{2}$ Migration to the country has changed dramatically over the last twenty or so years. The CR has ceased to be a purely transit country; following its entry into the Schengen system it has become a final migrant destination. In particular, entry and pre-accession preparations of the CR led to the adoption of a series of measures which approximated Czech legislation to European law. Despite several years of development, it cannot be said that CR integration policy fully complies with foreigners and the reality of European legislation. For logical and analytical reasons the following text is divided into two main parts. The first part presents the development of migration and integration policy (these policies are closely connected in Czech reality), while the second part will analyse how migration and integration policies currently function at the state and local level. From a chronological viewpoint, the text will be divided into time periods derived from publications that deal with migration and integration policy (see Baršová \& Barša, 2005, pp. 221-226; Kušniráková \& Čižinský, 2011, p. 498). There are six periods: 1990-1995, 1996-1999, 1999-2004,

${ }^{2}$ Migration and integration policies were very strict because migration was connected with special permission. Central state authorities issued permission for traveling abroad and migration across borders was severely restricted and strictly controlled (see more Jílek, 2010). 
2005-2007, 2008-2014, and the latest one, which has been affected by the migration crisis: from 2015 onwards.

The first period (1990-1995) is known as liberal and may be defined as laissez faire. After 1990 the CR returned to a group of open and transforming states aiming to adopt democracy. There was a coexistence of old rules from the communist era ${ }^{3}$ with new adjustments that needed to be adopted, for instance, the Convention on the Status of Refugees. Opening up to the world made it necessary for the country to adopt the Act No. 216/1990 Coll. on Travel Documents and Traveling Abroad. The CR was a transit state, but many refugees from Western Balkan countries and migrants from the post-Soviet area arrived in the CR to stay. ${ }^{4}$ The legislation reacted to this reality and started to regulate entry and stay in the CR. In 1992 a Law ${ }^{5}$ was passed which aimed to record incoming foreigners and control illegal immigration or violation of laws by foreigners. The state began to watch foreigners' length of stay more closely and set rules for long- and short-term stay and regulated the rules of visa policy. On the one hand, the Czech Republic was open to migrants; on the other hand, rules on how to acquire Czech citizenship and permanent residence were very strict. According to the law, ${ }^{6}$ a foreigner could obtain a permanent residence permit only in the case of family reunification or in humanitarian cases (Baršová \& Barša, 2005, pp. 221-222).

The second, restrictive, period (1996-1999) was characterised by a gradual tightening of the rules of migration policy of the Czech Republic. Two reasons have been identified: 1) a national economic crisis in 1997-1998, which brought about increased unemployment and fears of a growing number of immigrants, and 2) the intent of the Czech Republic to join the EU and the associated need to harmonise Czech legislation with EU regulations.

These were the main reasons that the second period involved a series of changes which led to stricter rules for foreigners. The question is whether these changes may be interpreted in the context of Europeanisation or

${ }^{3}$ Specifically, it was law no. 68/1965 Coll., the stay of foreigners on the territory of the Czechoslovak Socialist Republic; and two decrees: Interior Ministry 69/1965 Coll., which issued detailed rules on the stay of foreigners on the territory of the Czechoslovak Socialist Republic; Interior Ministry Decree no. 2/1949 Sb., restoration of the visa requirement in relations with France.

${ }^{4}$ Migrants to the Czech Republic came mainly from Ukraine, Russia, and Vietnam after 1993 (Bartoňová, 2002, p. 71-72).

${ }^{5}$ Law no. 123/1992 Coll., the Residence of Foreign Nationals in ČSFR.

${ }^{6}$ See $\$ 7$ Law no. 123/1992 Coll., the Residence of Foreign Nation’s in ČSFR. 
that of globalisation. The pressure from the EU was not as huge as the influx of migrants, mostly from Western Balkan countries and post-Soviet areas. Europeanisation grew more prominent at the end of this period because of the pressure of the EU and the intent of the Czech Republic to join the EU, which had been a crucial aim since the end of communism. At the end of the 1990s, Europeanisation was a sign of consistency. The EU wanted enlargement and the Czech Republic was interested in joining the $\mathrm{EU}$, with a number of changes to its migration and integration policy. In any case, the Czech Republic continued its strict policy towards migrants seeking integration. The Law on Residence of Foreigners in the Czech Republic ${ }^{7}$ and Act no. 325/1999 Sb., on Asylum were very restrictive but brought about fundamental changes in comparison with the previous law no. 123/1992 Coll. (Baršová \& Barša, 2005, pp. 223-224). Foreigners were granted the opportunity to obtain permanent residence status if they had lived in the Czech Republic for over 10 years, which had not been the case under the previous law (123/1992). At the same time, the Foreigners' Residence Act introduced a rule which complicated the access of foreigners to the Czech Republic. A foreigner's request for a visa or residence permit had to be completed not in the Czech Republic, but at an embassy outside of the country. In the context of Europeanisation, Czech legislation reacted to European standards of asylum and visa policy. The Asylum Act brought about new terminology in this area and has been implementing the Dublin Convention and the London resolutions to this Act within the framework of the harmonisation of Czech law with that of the European Union (Dohnalová, 2012, pp. 41-43). The law is still valid today; however, it has undergone a total of 51 changes since 1999. ${ }^{8}$ During the first and the second period, the CR did not create a coherent and logical migration and integration policy. Mostly external influences may be observed as opposed to the internal will (of the state) to implement a set of legislation regarding migration and integration policy. Attempts to correct or partially fill gaps in the legislation may be observed during these periods. The process of Europeanisation is connected with the harmonisation of Czech law with European standards that were created in this period (Bauerová, 2016).

The third period (1999-2004) stood for convergence, and not only in the area of migration and integration policy. This was the first time that the CR had formulated a more complex integration policy. The pressure of

\footnotetext{
${ }^{7}$ Law no. 326/1999 Sb., the residence of foreign nationals CR.

8 The latest change will apply from 1st June 2017.
} 
the EU was highly apparent and the Czech government implemented and awarded projects in the area of data collection and research on the integration of immigrants. ${ }^{9}$ Underlying data formed the basis for the first integration strategy. The Czech Government Resolution of 1999 began issuing regular concepts for the integration of migrants. ${ }^{10}$ The Commission for Integration and associations for the promotion and awareness of immigrants were created at the level of the Ministry of the Interior (Baršová \& Barša, 2005, p. 233), while legislative activity was more conceptual. This was reflected in two documents, the first of which is titled "Principles of Integration of Foreigners in the Czech Republic" and consists of fifteen principles that emphasize equal access for all foreigners and the active approach of the government towards the integration of immigrants in the Czech Republic. These principles also promote the integration of foreigners into the majority society (Czech Government, 1999). The second document, titled "Conception of Integration of Foreigners in the CR", promotes the integration of foreigners as individuals (Czech Government, 1999), refers to respect for all cultures, but also to the authority of the Czech legal order (Baršová \& Barša, 2005, pp. 233-236).

In spite of EU pressure, the CR had the ambition to be the main arbiter in integration policy and this reality was connected with a very strong effort to assimilate foreigners. At the same time, the CR slowly started to transfer competencies in integration policy to local public authorities. Authorities were created at the district level for the integration of foreigners in 2001 (there were 73 offices in regional smaller cities and three offices in Prague, Brno, and Ostrava) (Czech Government, 2003). However, this was not a very successful local initiative, because these districts were closed in 2002. This was a reflection of an unsystematic approach and the inability of the state reacting to top-down Europeanisation. The complex of district authorities did not suit EU regional policy. Under the pressure of the EU, the CR created a set of regional authorities. The reality showed that local authorities did not develop a systematic integration of foreigners, mainly because the ministry level was the main actor which centralises

9 The CR had to harmonise visa duty with a special group of states because of harmonisation with European standards. In 2000 a visa requirement was introduced for citizens of Russia, Ukraine, and Belarus and a visa-free agreement was abolished with Kyrgyzstan, Moldova, Kazakhstan, and Turkmenistan (Bartoňová, 2002, p. 76).

10 Government Resolution dated July 7, 1999 no. 689. The first conception was adopted in 2000; conceptions are updated every five years. Concepts are an expression of a more systematic approach to integration policy. The term conception is used to refer to koncepce in Czech. It is used in this sense throughout the text. 
and develops the agenda of integration policy. The central authority does not possess insider knowledge of the local problems of foreigners and the local authority does not have enough power. It was mostly accession to the EU in 2004 that brought about strengthened cooperation with regional authorities ${ }^{11}$ and with mayors of regular municipalities and municipalities with extended powers. The main activities of local municipalities were lectures on the status of foreigners in the region.

Since the beginning there have been fundamental problems associated with the integration of migrants at the local level. The state has not adopted a law imposing an obligation on local authorities to deal with migrant integration issues. As a result, there has been great inequality in approaches to migrant integration. The issue of integration has not been addressed, nor, have a special adviser or trade unions been recruited to help foreigners to integrate. ${ }^{12}$ The primary problem has been the language barrier, often because local bodies have been unable to communicate with foreigners in a language other than Czech. At the local level, the Ministry of Interior has been cooperating with universities mostly in the field of integration of foreigners or preparing language courses for foreigners. Pre-accession talks forced the Czech Republic to rethink its relationship with foreigners. In addition, the social problems of foreign citizens were becoming increasingly apparent, which was why the CR decided to combine the issue of migrants with social aspects and transferred the agenda of migration and integration policies from the Ministry of the Interior to the Ministry of Labour and Social Affairs (effective from 1 January 2004). The latter ministry cooperated with private companies and awarded a contract for a special study to identify the main problems of foreigners living in the Czech Republic (Gabal, 2004). A Commission of the Ministry of Labour and Social Affairs for Integration was created as the deciding body for migrant integration. This commission represented various societal interests because its members were representatives of the government, academia, non-governmental organisations, associations of foreigners, trade unions, associations of regions and the Unions of Towns and Municipalities of the Czech Republic (Czech Government, 2003).

At the end of this period, the Czech Republic intensified its activities in the area of migration and integration policy. Two main reasons may be

11 Regional offices were replaced by a system of district offices in 2002.

12 The group of active cities includes Pilsen, Brno, Prague, Karlovy Vary, and Pardubice. These cities are interesting in terms of concept implementation. 
observed, the first of which was a relatively large increase in the number of foreigners in the Czech Republic. In 2002, foreigners accounted for 1.8\% of the population, while in mid-2005 this had already increased to $2.5 \%$ (Czech Statistical Office, 2016b). The second reason lay in new Czech migration and integration policies, which were a result of EU pressure. The proactive approach of the state was also a result of the opportunity to absorb funds from the five funds provided by the EU. ${ }^{13}$ In 2003, the government policy on migration of foreigners was created (Czech Government, 2003a), which referred to the country's involvement in the European integration process. Namely, the Czech Republic was committed to addressing migration policy at all levels. ${ }^{14}$ The state responded to the document titled "Common Basic Principles for Immigrant Integration Policy in the EU", drafted by the Council of the EU (Council of the EU, 2004). In practical terms, the document was very general and did not provide any new solutions in the area of migration policy of the Czech Republic. A more active approach to foreigners was reflected by the project "Selection of Qualified Foreign Workers", created by the Ministry of Labour and Social Affairs. This project was meant to support immigrants with high qualifications. The advantage of the project was that skilled workers could apply for permanent residence after three years of residence in the CR. On the other hand, there were some disadvantages: the state did not help them find employment nor did it assist them with visa applications. At first sight, the number of potential applicants was very limited and the number of applications for admission to the programme eventually turned out to be very low. The project itself clearly showed restrictive features, significantly limiting the number of successful applicants..$^{15}$

In spite of the (more) active attitude of the state in this period, some problems can be identified. The first conception of migrant integration did not clearly state the goal of integration policy and how the integration of migrants would be operationalised. It was more than clear that the CR was still very strict in its migration policy. There was no division of labour

13 Fund 1: EQUAL Community Initiative Programme - II. round programme INTI - Pilot Fund 2: Project on Integration of Third-Country Nationals, Fund 3: the European Refugee Fund, Fund 4: Operational Programme Human Resources Development and Fund 5: the Single Programming Document for Objective 3 of NUTS 2 Prague (see more: Czech Government 2003).

14 Civil society, non-government organisations, state institutions, and cooperation with OSN and EU

15 There were 3,500 foreigners who joined the project (1,806 participants and 1,700 family members) (Ministry of Labour and Social Affairs, 2010). 
and it was unclear which activities were to be performed by the state and which by other actors. The first migrant integration programme showed the fundamental role of local authorities; however, there was no special law or order that obligated those authorities to deal with integration.

The fourth period is called neoliberal and encompassed the period 20042007/2008. This was a period of significant economic growth and low unemployment. A labour shortage was offset by imports of lower-skilled labour from abroad, mainly from eastern parts of Europe, using employment agencies. With accession to the EU and the Schengen Area (21 December 2007), the Czech Republic ceased to be a transit country and became a target country (Czech Government, 2004). The Czech Republic was therefore aware of the need to revise the concept of immigrant integration and address issues related to social integration. However, the problem was that the country had not completed its migration policy nor had it clearly stated the goals of its integration policy (Czech Government, 2004). The Czech Republic was at the imaginary beginning of a long process that was not feasible without fundamental changes in both the legislative and non-legislative area. At the same time, it had not been determined when the concept would be completed. First of all, the government formulated the main areas of integration policy in the new concept (adopted in 2005). It was identified that the successful integration of foreigners included requirements in the following areas: Czech language skills (spoken production at level $\mathrm{B} 1^{16}$ ); economic self-sufficiency (foreigners must annually obtain confirmation of the duration of employment and renewal of employment); orientation in society (the CR only planned to issue a general brochure with basic information about the country); and relations between foreigners and the majority society (the problem of negative attitudes towards migrants in the CR, as well as the role of NGOs, municipalities, and regions) (Czech Government, 2005). The question was the measurability of these values because not all could be expressed in concrete terms. In addition, the development of all areas was at the initial stage and the question was how the issue would continue to develop after 2005.

In subsequent years, it became clear that the state authorities were aware of the need to refine the partial integration policy. The state evaluated the changes and adjustments, and acknowledged weaknesses, especially in the area of social assistance. The year 2008 saw a reform of the

16 The language level is in accordance with the Common European Framework of Reference for Languages - CERF. 
concept of the integration of foreigners in the CR. One change was the transfer of the migrant integration agenda from the Ministry of Labour and Social Affairs to the Ministry of the Interior (Ministry of the Interior, 2015). ${ }^{17}$ Another change was necessary to connect the integration of migrants with the active role of the local population, who would need to accept foreigners. The active participation of NGOs clearly showed that social aspects were absent from the integration of foreigners. ${ }^{18}$ Moreover, individual aspects of integration were often solved in a very unsystematic manner because each ministerial department formulated its own strategy for integration. The state formulated the challenge of creating a coherent integration policy and a long-term framework for the integration of foreigners was developed later in 2006. However, this was not a legislative regulation that would amend the regulation activities of local actors in the field of integration. The law did not require local actors to address the issue of migration and integration of foreigners; instead the text contained only a general call for cooperation to be developed at the local level.

EU membership was connected with a strong pressure to reform migration and integration policy. This could be seen in 2007, when a law on the entry and residence of foreigners came into force. During the period of economic crisis, the CR grew more careful in relation to migrants. One example of this was the Green Card Project, initiated by the Ministry of Industry in 2007. The Czech Republic wanted qualified workers from abroad, but the economic crisis postponed the start of the project by two years. Moreover, the duplication of CR and EU activities became apparent. In the same period, the EU had adopted the Blue Card Directive, which was related to the employment of qualified foreign workers and thus the Green Card Project became redundant (Dohnalová, 2012, pp. 44-45).

Different activities or passive attitudes could be seen at the local level. Significant activity could only be observed in Prague, Brno, and Pilsen, where bodies for the integration of foreigners were created. A working group for the integration of foreigners was founded in the south of the country and teaching programmes for ethnic minorities were realised in Karlovy Vary and Ústí nad Labem. The reason why the integration policy

17 The issues and agenda of migrants and foreigners had started to be interpreted as a security problem. The connection between integration and migration policy and security issues emerged on accession to the Schengen Area in 2007.

18 One of the reasons for this was the transfer of the migrant integration agenda to the Ministry of the Interior. Because the integration agenda was mostly connected with security, social aspects had taken a back seat. 
was only practised in a few places was determined by the number of foreigners. ${ }^{19}$ The passivity of local authorities was caused by the significant underfunding of this policy. Twenty million CZK were invested in 2004, compared with only 12 million CZK in 2005 (see Czech Government, 2004). Despite efforts to change the Agenda for Foreigner Integration, there were still rules that made it difficult to integrate foreigners. Foreigners were unable to change employers, even after 20 years of continuous work in the country. Work permits had to be renewed annually and had a strong anti-integration connotation. In addition, the Ministry of the Interior had once again become the main actor in managing integration policy (Government Resolution, 2008), which steered the emphasis away from the social aspects of integration. NGOs in particular criticised the change openly (Dohnalová, 2012, pp. 45-46).

The neo-restrictive period (2008-2013/2014) led to the transformation of migration and integration policy of the Czech Republic because of the economic crisis. The reality of the crisis reduced the number of jobs and therefore the Czech Republic also introduced a more restrictive policy to reduce the numbers of immigrants. The Czech Republic defended these restrictive steps in an effort to protect the employment of Czech citizens. Moreover, foreigners were found to be connected with crime (for example economic crime, drug crime, and illegal crossing of the state border) (Czech Government, 2009; Kušniráková \& Čižinský, 2011, p. 498).

Earlier periods (mostly 1999-2007) had opened up and liberalised Czech migration and integration policy to bring it closer to European standards. The process of Europeanisation was positive. Internally, the CR had no reason to strictly refuse the "European" reality of integration and migration policy. However, the post-2008 period, which was connected with the economic crisis and a larger wave of migration to Europe as a result of the Arab Spring, showed a gradual shift away from Europeanisation in the area of migration and integration policy. ${ }^{20}$ This would culminate in particular after 2015. Laws proposed in the past were not accepted; for instance, rules on health insurance for foreigners and Czech language methodology were not accepted. There were only a few positive changes;

${ }^{19}$ Foreigners tend to concentrate in certain geographical areas; most live in Prague, the Karlovy Vary Region, and the Moravian-Silesian Region (see more Czech Statistical Office, 2014).

${ }^{20}$ Even the reality of the Arab Spring has not brought about significant changes to the national composition of the Czech Republic. According to the census results (2011), "Czech Republic remains nationally rather homogeneous" (Czech Statistical Office, 2014). 
a case in point was an amendment to the Education Act on Primary Education, which stipulated that the costs would be covered (even in secondary education) for all children, regardless of whether they had obtained permission to stay in the CR. At the end of 2008, local authorities started to tackle emergency projects at the municipal level. The problem was that the local level was able to respond to ad hoc situations, but long-term activity was not realised.

In particular, restrictive or very general laws prevailed. For example, Government Resolution No. 1205/2009 of 16 September 2009 limited foreigners' options to apply for a long-term visa (in excess of 90 days), not only because of the economic crisis but also because of corruption problems at embassies in Ukraine or Vietnam. A new law on language rules was accepted, stipulating that in order to qualify for permanent residence, it was necessary to know Czech at level A1. This is a relatively low threshold and in the long term poor language skills often reduce the likelihood of foreigners integrating into society and the labour market. It became clear that foreigners should learn some basic information about the CR before entering the country and schemes began to be introduced in foreign consulates (Pořizek, 2010). Czech legislation had to respond to the Visa Code, a regulation of the European Parliament and of the Council of EU, and to harmonise visa procedures. First of all, Czech legislation reacted and implemented (on 5 April 2010) the Visa Code to Czech law. January 12011 saw the entry into force of an amendment to Act No. 326/1999 Coll., on the Stay of Foreigners in the Czech Republic. The amendment tightened conditions for foreigners, who had to indicate the purpose of their business as the reason for their stay, mainly due to the increase in immigration companies. There was a change in the conditions of travel health insurance for foreigners and the introduction of biometric ID cards for foreigners. January 12011 also saw the entry into force of an amendment to Act No. 325/1999 Coll., on Asylum, also mainly due to the implementation of newly adopted EU legislation. The link between migration and integration policies is reflected in two documents, namely the updated "Concept for the Integration of Foreigners Living Together 2011" (Ministry of Interior, 2011) and the procedure for the implementation of the updated "Concept of Immigrant Integration - Living Together in 2012" (Czech Government, 2016). From the integration perspective, the establishment of a system of centres for the integration of foreigners in the CR was highly successful. Centres were founded in regions in 2009. These centres provide counselling for foreigners and courses to help them integrate in the CR (Dohnalová, 2012, pp. 46-49). The centres were es- 
tablished and continued to operate with financial support from the EU. The activities of the centres declined after 2015 because financial support from the EU became unavailable (see below). In addition, it should be noted that the volume of programmes offered in each region varies; i.e., the level and the frequency of services is not the same.

The most recent period, since 2015, reflects a clear influence of the migration crisis. Persons from third countries outside the EU have been newly included in integration projects, as well as persons enjoying international protection. In earlier periods these groups were addressed in other policy documents. The CR is aware that the number of foreigners is growing. ${ }^{21} \mathrm{It}$ is evident that most foreigners have the intention of acquiring permanent seating and acquiring citizenship in the country. This may be explained as a consequence of the adoption of new Law No. 186/2013, which recognises dual citizenship. Furthermore, the CR has adopted a law that grants equal rights in education to all, without distinction on the basis of their country of origin. The integration of foreigners is faced with many problems, which, inter alia, arise from the fact that there are thirty times as many foreigners living in the country than in $1989 .{ }^{22}$ Since 2002, when the CR completed the pre-accession process, there has been a gradual increase in the number of foreigners migrating to the Czech Republic. Especially since 2004, there has been a significant increase in the number of immigrants due to the favourable economic situation and labour shortages. The CR attracted foreigners mainly due to labour migration in the neoliberal period mentioned above. This growth culminated in 2008, in part also as a result of CR entry into the Schengen Area on 21 December, 2007. In the following years, especially 2009 and 2010, there was a decline in the migration of foreigners to the CR because of the economic crisis and stricter rules regarding CR migration policy. It has also been possible to observe a partial increase in the number of immigrants since 2015. The year 2015 is associated with the early European migration crisis and a growing number of immigrants in all EU countries. On 30 June 2016, the CR recorded 107,614 legal immigrants from Ukraine (almost $22.5 \%$ of all immigrants in the country), among other countries of origin: Slovakia (21.8\%), Vietnam (12\%), Russia (7.4\%), Germany (4.4\%),

21 There were 254,294 foreigners living in the Czech Republic in 2004; 278,312 in 2005; 321,456 in 2006; 392,315 in 2007; and one year after the accession to the Schengen Area (2008) there were 437,765 (Czech Statistical Office, 2014).

22 According to the Czech Statistical Office (2016c), 10,564,900 people live in the Czech Republic (30 June 2016), about 4.5 per cent of whom are foreigners. 
Poland (4.2\%), and Bulgaria (2.4\%) (Czech Statistical Office, 2016a). A special group included those applying for international protection. The number of asylum-seekers has increased since 2014 in comparison with the years before. ${ }^{23}$ However, this shows that, despite the increase in the number of asylum-seekers, the CR is not a target country for immigrants, but rather a transit country (Ministry of the Interior, 2016). Nevertheless, the CR has tightened rules for the integration of migrants. Additionally, immigrants from Africa and Syria are not heading to the Czech Republic. The national composition of migrants has not changed.

Unwillingness to adapt to European rules was seen in 2015, when the Czech Republic refused to accept a quota system under which the country would have been required to accept the first 797 immigrants from Italy, 531 from Greece, and 525 people from outside the EU (European Commission, 2015). Following the adoption of the second implementation package, the CR would have had to accept a total of 2,978 immigrants. On the issue of the adoption of quotas, the Czech Republic did not side with Slovakia, which filed a lawsuit against quotas. The main argument for not siding with Slovakia was that the CR did not want to lose its position within the EU (CT24 Czech television, 2015, September 23). Despite the number determined by the quota (1,591 immigrants), the CR stood up to this European Council decision very carefully. ${ }^{24}$ The migration crisis showed both legal and practical unpreparedness for a greater influx of migrants.

In the area of integration policy, a number of problems have persisted for a long time. The Czech Republic essentially seeks to assimilate foreigners and the general public also prefers this model. The effort to assimilate new citizens is clear from the very definition of integration policies. "The aim of the integration policy in relation to migration is to promote the integration of foreigners into society, to achieve peaceful coexistence with foreigners, avoid creating negative social phenomena and to ensure the protection of the rights and security of all inhabitants of the Czech Republic." (Czech Government, 2016). Therefore, integration policies should take

23 The largest number of applicants for international protection $(11,400)$ was recorded in 2003, followed by 5,459 in 2004; 4,021 in 2005; 3,016 in 2006; 833 in 2010; 707 in 2013; 1,525 in 2015; and 1,273 in 2016 (Ministry of the Interior, 2017).

24 In February 2016, the Czech Republic decided to accept the first 20 foreigners from Greece and Italy under the quota system. However, only seven Syrians were cleared for entry, while the remaining immigrants were refused entry because of a lack of confirmation of their identity. Of the seven immigrants who were cleared for entry, only four arrived in the Czech Republic. The other three left Greece because they disagreed with their relocation to the Czech Republic (Parlamentnilisty, 2016). 
into account the specificities of particular groups of foreigners. The weaknesses and difficulties of the integration policy are reflected in the Migration Manifesto of 2015 (Konsorcium nevládních organizaci pracujicich s migranty $\mathrm{v} \check{C} \mathrm{R}, 2015$ ), which basically identifies the main weaknesses of the integration of migrants. The manifesto highlights the failure to comply with laws within the deadline, e.g. in residential settlement documents under Law 326/1999 on the Residence of Foreigners, or in application for international protection. It is only possible to apply for a visa within the first 90 days in the CR. Integration does not begin with the entry of migrants to the CR, but only once international protection has been granted. Local levels play a major role but only Prague and the South Moravian region have their own concept of the integration of migrants. The system of integration is clearly centralised and activities in the integration policy are initiated by the Ministry of the Interior. Integration projects are intended only for people from third countries, not for EU citizens and those without residence permits.

The main objectives of integration are good language skills, which still need to be no higher than level A1 to acquire permanent residence (see above). The local authorities should play a key role in integration policy. For this reason, the position of regional coordinator was established. The problem is that coordinators do not have the competence for full performance. The strongest integration actors are centres for the integration of foreigners, which use support of non-profit organisations and work in cooperation with cities. As has already been noted, the CR did not allocate enough money for the centres to operate. Moreover, there are still disparities at the local level. Emergency projects have been replaced by integration projects, which are funded by the Ministry of the Interior. However, these projects only undertake only a narrow scope of jobs. They have only been implemented in five cities (Pilsen, Hradec Kralove, Pardubice, Teplice and Prague Libuš) and only in ten municipalities. Local actors and non-profit organisations are actively involved in the integration of migrants, but their activities are related only to regions where large numbers of foreigners are concentrated. Activities are realised mostly in Prague because more than half of the migrants live in Prague or in the Central Bohemia Region (Drbohlav, 2011, p. 405).

The most recent period, connected with the migration wave, showed that migration and integration policy did not work in practice and pointed to legislative gaps. These troubles are connected with pressure from the EU to accept quotas for migrants on the one hand, and with strong nationalism and populism in Czech society on the other. Interest in Europeanisa- 
tion in the area of migration and integration policy either does not exist or is very low. The Czech political elite prefer their own "state" interests. In practice, this means greater pressure on the assimilation of migrants and the effort to connect migrants with security threats.

\section{Conclusion}

The Czech Republic was a transit state for a long time and troubles connected with migrants and integration policy were interpreted as important. In reality, however, migration and integration policy were relegated to second-class status. The issue of migration and migrants has been securitised by the political elites, and civil society has perceived migration and the potential integration of migrants very negatively, particularly in recent years. The restrictive nature of migratory and integration policies is a characteristic feature that has been strengthened considerably after 2015. The current integration policy displays a fear of differences and imposes the condition of absolute assimilation in an effort to integrate migrants. The implied effort is stronger as the EU faces a growing migration wave. One reason for this restrictive position is the country's historical "inexperience" with migrants and the differences that are typical for the Czech Republic for most of the second half of the $20^{\text {th }}$ century.

In spite of Europeanisation, three main periods can be observed. The first period (1989-1996) is connected with the post-communist period, when the CR adapted to the reality of an international system. The position with regard to migrants was quite passive and for the most part adaptation to international rules can be observed. Later, the state filed an application to join the EU. In the second period (1996-2010), the state initiated harmonisation with European law and all the rules were tightened. The CR implemented the Dublin Convention, the London Resolution, and all the resolutions that led to accession to the Schengen Area. In this period, the CR was an obedient state that implemented all the EU legislation into its national laws. Greater attention was paid to migration than to integration policy. Integration policy was developed after the year 2000 because of the pressure of the EU. However, many problems have persisted until today (see below). The third period, post 2010, is connected with de-Europeanisation; CR ceases to be an obedient member state.

If we summarise the process of Europeanisation, in 1993 the Czech Republic retained strict rules allowing permanent settlement in its territory. 
The main motive for this was a) the arrival of migrants, first from the post-Soviet area (Ukraine and Belarus in particular) and the Western Balkans, and subsequently from Vietnam, and b) economic crises (in the late 1990s and at the end of the 2010s). Currently, although there are migrants from other regions (the Middle East and Africa) in the Czech Republic, their number is in fact negligible.

Pre-accession talks and accession to the EU and to the Schengen Area resulted in greater acceptance of European law. However, a number of changes were made at a late stage or did not work in practice. There has been no Europeanisation of migration and integration policies since 2015. The Czech Republic rejected the long-term and short-term instruments of both policies. The quota system was refused as was the case in the other Visegrad countries. The migration crisis has brought about increased public interest and greater activity of migrant integration policy-makers. This is not a manifestation of Europeanisation (top-down) but of the state defending its own interests.

A special feature is the involvement of local authorities in migration and, in particular, integration policies. History has shown that in the past there was no need to address the issue of foreigners at the local level. The central authorities played a key role. Decentralisation only took place after 1996, when the Czech Republic created a system of regional authorities under pressure from the EU. Their activities are limited and the Ministry of the Interior (and previously the Ministry of Labour and Social Affairs) remains the decisive arbiter of integration and migration policy. The strong position of the central authorities stems from the fact that local authorities have no legal obligation to implement integration policy in practice. This is a paradoxical situation. The state recognises the crucial role of local authorities in the integration of foreigners, but at the same time does not delegate sufficient powers or finances to the local authorities. The financial requirement of the integration policy is another weakness. After 2004, the CR started to absorb financial support from European funds. Europeanisation of migrant integration (coupled with EU financial support) led, amongst other things, to the creation of a network of regional integration centres. Since 2015, the state has not been allocating sufficient funds for these to function and the role of integration centres has weakened. Other actors of integration policy are non-profit organisations. These organisations are quite active but overall their activity is connected mostly to Prague, where most foreigners are concentrated. This is one of the main problems: the CR is quite homogenous and most foreigners are concentrated in a few places (Prague and the Central Bohemian Region). Other regions do not feel the need to be active in integration policy. 
It is impossible to say that the integration policy is working well. Integration problems are still present, for example: persistent legislative shortcomings, foreigners have no right to vote at the local level, a place of residence can only be obtained after five years of residence in the CR, and it is only possible to apply for citizenship after ten years of permanent settlement in the country. Another problem is the health insurance system for foreigners who have not yet become part of the public health insurance system. Yet another long-term problem is the cultural resistance of society, which requires cultural assimilation. The local level is the most passive and only becomes active when it performs assigned tasks arising from the activities of the Interior Ministry.

The most recent period (mostly post 2015) has meant that the CR itself feels the need to create a better-functioning integration policy. In the future, however, the state must overcome all its past troubles. It is necessary for the most part to develop cooperation with local authorities and implement an integration policy that would harmonise the coexistence of the majority society and foreign nationals.

\section{References}

Bartoňová, D. (2002). Migrace [Migration]. In Z. Pavlík, \& M. Kucera (Eds.) Populační výroj České republiky 1990-2002 [Population development of the Czech Republic 1990-2002] (pp. 69-80). Retrieved from http://popin.natur. cuni.cz/html2/index.php?item $=8.4 . e$

Baršová, A., \& Barša, P. (2005). Přistěhovalectví a liberální stát [Immigration and the liberal state]. Brno, Czech Republic: Masarykova univerzita.

Bauerová, H. (2016). Migrační politika EU jako nedokonalý př́klad top-down europeizace [EU migration policy as an imperfect example of top-down Europeanization]. Politics in Central Europe, 12(15), 89-113.

Börzel, T. (2005). Europeanization: How the European Union interacts with its member states. In S. J. Bulmer \& C. Lequesne (Eds.), The member states of the European Union (pp. 45-69). Oxford, United Kingdom: Oxford University Press.

Cabada, L., \& Hloušek, V. (2009). Eurovolby 2009: Prostor pro evropeizaci politických stran ve středovýchodni Evropě? [Euro election 2009: Space for the Europeanisation of political parties in Central Eastern Europe?]. Plzeň, Czech Republic: Vydavatelství a nakladatelství A. Čeněk.

Council of the EU (2004). Common Basic Principles on Integration (146/15) [Press Release]. Retrieved from https://www.consilium.europa.eu/ueDocs/cms_ Data/docs/pressData/en/jha/82745.pdf

CT24 Czech Television (2015, September 23). Ministři vnitra prijali uprchlické kvóty, Slovensko je odmítá respektovat [Interior ministers have accepted refugee 
quotas, and Slovakia refuses to respect them]. Retrieved from http://www. ceskatelevize.cz/ct24/svet/1588874-ministri-vnitra-prijali-uprchlicke-kvoty-slovensko-je-odmita-respektovat

Czech Government (1999). Zásady koncepce integrace cizinců na území České republiky. [Principles of integration of foreigners]. Retrieved from http://cizinci. cz/repository/2154/file/Zasady_vlady_integrace.pdf

Czech Government (2003). Koncepce integrace cizincu do konce roku 2004 a její dalši rozvoj v roce 2005 [Concept of integration of foreigners by the end of 2004 and its further development in 2005] [Conception]. Retrieved from http://webcache.googleusercontent.com/search?q=cache:2ft5qq68MEkJ:www.kraj-lbc.cz/public/social/kic_vlada_material1_05_dae52b915b.rt$\mathrm{f}+\& \mathrm{~cd}=5 \& \mathrm{hl}=\mathrm{en} \& \mathrm{ct}=\mathrm{clnk} \& \mathrm{gl}=\mathrm{cz} \& \mathrm{client}=$ firefox $-\mathrm{b}-\mathrm{ab}$.

Czech government (2003a). Koncepce integrace cizincui na území České republiky a dalši rozvoj této koncepce po vstupu České republiky do EU [Concept of the integration of foreigners in the territory of the Czech Republic and further development of this concept after the accession of the Czech Republic to the European Union] [Resolution]. Retrieved from https://kormoran.vlada.cz/usneseni/usneseni_webtest.nsf/0/D376DFB23057E7E6C12571B60070FBF3

Czech Government (2004). Koncepce integrace cizincư v roce 2005 a její další rozvoj [The concept of integration of foreigners in 2005 and its further development] [Resolution]. Retrieved from http://cizinci.cz/repository/2154/file/ usneseni_2006_126_KIC.pdf

Czech Government (2005). Koncepce integrace cizincư v roce 2005 a jeji dalši rozvoj [Concept of integration of foreigners in 2005 and its further development] [Conception]. Retrieved from file://C:/Users/MUP/Downloads/KIC_2006_a_ Postup_pri_realizaci_KIC-2006_-_usneseni_vlady_c_126-2006.pdf.

Czech Government (2009). Vládní rozbodnutí č. 171 [Government resolution no. 171] [Resolution]. Retrieved from https://kormoran.vlada.cz/usneseni/ usneseni_webtest.nsf/0/813889E9A7A4AA9EC125755B00460A14/\$FILE/171\%20uv090209.0171.pdf

Czech government (2016). Vládní rozhodnutíc č. 26 - Koncepce integrace cizinců-Ve vzájemném respektu a Postup při realizaci Koncepce integrace cizinců v roce 2016 [Government resolution no. 26 - Concept of the integration of foreigners - In mutual respect and Procedure in implementation of the Concept of integration of foreigners in 2016] [Resolution]. Retrieved from http://www.mvcr.cz/ clanek/integrace.aspx

Czech Statistical Office (2014). Národnostni struktura obyvatel [National Population Structure] [Analysis]. Retrieved from https://www+-so.cz/documents/10180/20551765/170223-14.pdf

Czech Statistical Office (2016a). Předběžné údaje zveřejněné Ředitelstvím cizinecké policie [Preliminary data published by the Directorate of the Foreign Police] [Report]. Retrieved from https://www.czso.cz/documents/11292/45942355/1606_ c01t13.pdf/0d16a67f-f228-49f7-bd2c-aa1d8c671182?version=1.0

Czech Statistical Office (2016b). Cizinci 2016 [Foreigners 2016] [Report]. Retrieved from https://www.czso.cz/csu/cizinci/cizinci-pocet-cizincu 
Czech Statistical Office (2016c). Foreigners by type of residence and sex [Statistics]. Retrieved from https://www.czso.cz/csu/cizinci/predbezne-udaje-zverejnovane-rs-cp

Dohnalová, E. (2012). Úvod do sociální práce s migranty [Introduction to social work with migrants]. Olomouc, Czech Republic: Caritas.

Drbohlav, D. (2011). Imigrace a integrace cizinců v Česku: několik zastavení na cestě země v její migrační proměně z Davida na Goliáše [Immigration and integration of foreigners in the Czech Republic: Several stops on the way of the country in its migration transformation from David to Goliath]. Geografie, 4(116), 401-421.

European Commission (2015). Dalši krok komise v otázce migrace [European Commission makes progress on Agenda on Migration] [Press release]. Retrieved from http://europa.eu/rapid/press-release_IP-15-5039_cs.htm

Fink-Hafner, D., \& Lajh, D. (2003). Managing Europe from bome: The Europeanisation of the Slovenian core executive. Ljubljana, Slovenia: Faculty of Social Science.

Gabal Ivan analyses and consulting (2004). Analýza postavení cizinců dlouhodobě žijících v ČR a návrh optimalizačních kroků [Analysis of the long-term status of foreigners living in the Czech Republic and proposal for optimization steps] [Work study]. Retrieved from: https://www.mpsv.cz/files/clanky/511/ postaveni_cizincu.pdf

Hloušek, V., \& Pitrová, M. (2009). Pojem evropeizace a jeho konceptualizace [The concept of Europeanization and its conceptualization]. In V. Fiala \& kol. (2009) Evropeizace zájmů. Politické strany a zájmové skupiny v České republice [Europeanization of interests: Political parties and interest groups in the Czech Republic] (pp. 15-43). Brno, Czech Republic: MPÚ.

Jílek, T. (2010). Speciky ostrahy česko-bavorské státní hranice v období “železné opony" 1948 - 1989. [Specialties of the Czech-Bavarian State Border Guard "in the Iron Curtain Period" 1948 - 1989 ]. In Morávková, N. (2010). Přes pernou bráz socialismu a míru. Sborník z kolokvia katedry bistorie Fakulty pedagogické Západočeské univerzity v Plzni, Středisko orální historie [Despite the solid barrier of socialism and peace.Colloquium of the Department of History of the Faculty of Education of the University of West Bohemia in Pilsen, Center for Oral History] (pp. 8-14). Olomouc, Czech Republic: ViaCentrum pro S.

Konsorcium nevládních organizací pracujících s migranty v ČR [Consortium of Migrants Assisting Organizations in the CR] (2015). Migrační manifest 2015 [Migration Manifesto 2015]. Retrieved from http://www.migracnimanifest. $\mathrm{cz} / \mathrm{cz} / \mathrm{index} \cdot \mathrm{html}$

Kušniráková, T., \& Čižinský, P. (2011). Dvacet let české migrační politiky: liberální, restriktivní, anebo ještě jiná? [Twenty years of Czech migration policy: Liberal, restrictive or otherwise?]. Geografie, 116(4), 497-517.

Ministry of Labour and Social Affairs (2010). Tisková informace "Výběr kvalifikovaných zabraničních pracovnikü" konči [Press release "Selection of Qualified Foreign Workers" Ended][Press release]. Retrieved from www.mpsv.cz/files/ clanky/9997/13122010.pdf 
Ministry of the Interior (2011). Koncepce integrace cizincü žijeme společně 2011 [Concept for the Integration of Foreigners Living Together-2011] [Conception]. Retrieved from www.mvcr.cz/soubor/uv-09022011-pdf.aspx

Ministry of the Interior (2015). Koncepce integrace cizinců na území ČR [Concept of integration of foreigners in the Czech Republic] [Conception]. Retrieved from https://ec.europa.eu/epale/cs/resource-centre/content/koncepce-integrace-cizincu-na-uzemi-cr

Ministry of the Interior (2016). Statistická zpráva o mezinárodni ochraně po měsících $v$ roce 2016 [Statistical report on international protection for each month in 2016]. Retrieved from http://www.mvcr.cz/migrace/docDetail.aspx?docid $=21979264 \&$ docType $=$ ART $\&$ chnum $=1$

Ministry of the Interior (2017). Statistické zprávy o žadatelích o mezinárodní ochranu a azylantech [Statistical reports on applicants for international protection and asylum]. Retrieved from http://www.mvcr.cz/clanek/mezinarodni-ochrana-253352.aspx

Morávková, N. (2010). Přes pevnou hráz socialismu a míru [Despite the solid barrier of socialism and peace]. In Sbornik z kolokvia katedry bistorie Fakulty pedagogické Západočeské univerzity v Plzni, Středisko orální historie [Colloquium of the Department of History of the Faculty of Education of the University of West Bohemia in Pilsen, Center for Oral History] (pp.). Olomouc, Czech Republic: ViaCentrum pro S.

Parlamentnilisty (2016). ČR se zařizuje podle kvót a prijímá první uprchlíky [The Czech Republic is allocated according to quotas and accepts the first refugees]. Retrieved from http://www.parlamentnilisty.cz/arena/monitor/ CR-se-zarizuje-podle-kvot-a-prijima-prvni-uprchliky-432819

Pořízek, P. (2010). Přístup $k$ podání žádosti o vízum a regulace počtu podaných žádostí [Access to visa application and regulation of the number of applications submitted]. Retrieved from http://migraceonline.cz/cz/e-knihovna/pristup-k-podani-zadosti-o-vizum-a-regulace-poctu-podanych-zadosti

Radaelli, C. M. (2003). The Europeanization of public policy. In K. Featherstone \& C. M. Radaelli(Eds.), The politics of Europeanization (pp. 27-56). Oxford, United Kingdom: Oxford University Press, https://doi.org/10.1093/0199252092.003.0002

Schmidt, V. A., \& Radaelli, C. M. (2004). Policy change and discourse in Europe: Conceptual and methodological issues. West European Politics, 27(2), 183-210, https://doi.org/10.1080/0140238042000214874.

\section{Legal sources}

Dodatek k zákonu č. 325/1999 Sb. o azylu [Amendment to Act on Asylum], Official Gazette No. 325.

Dodatek k zákonu č. 326325/1999 /1999 Sb. o pobytu cizinců v České republice [Amendment to Act No. 326/1999 Coll., on the Stay of Foreigners in the Czech Republic]. 
Vládní rozhodnutí z 23. července 2008 č. 979 [Government Resolution dated 23 July 2008], Official Gazette No. 979.

Vládní rozhodnutí ze 7. července 1999 č. 689 [Government Resolution dated July 7, 1999], Official Gazette No. 689.

Vyhláška ministerstva č. 2/1949 o obnově vízové povinností s Francií [Ministry Decree on Restoration of the Visa Requirement in Relations with France], Official Gazette No. 2/1949 Sb.

Zákon č. 123/1992 Sb. o pobytu cizinců v ČSFR [Law on the Residence of Foreign Nation's in ČSFR], Official Gazette No. 123/1992 Coll.

Zákon č. 216/1990 Sb. O cestovních dokladech a cestování do zahraničí [Law on Travel Documents and Traveling Abroad], Official Gazette No. 216/1990 Coll.

Zákon č. 325/1999 Sb. o azylu [Law on Asylum], Official Gazette No. 325/1999 $\mathrm{Sb}$.

Zákon č. 326/1999 o pobytu cizinců v ČR [Law on the Residence of Foreign Nationals in CR], Official Gazette No. 326/1999 Coll.

Zákon č. 68/1965 Sb. o pobytu cizinců na území Československé socialistické republiky [Law on the Stay of Foreigners in the Territory of the Czechoslovak Socialist Republic], Official Gazette No. 68/1965 Coll.

Zákon č. 69/1965 podrobně upravující pravidla pobytu cizinců na území Československé socialistické republiky [Law on Rules on the Stay of Foreigners in the territory of the Czechoslovak Socialist Republic], Official Gazette No. 69/1965 Coll.

Zákon o státním občanství 186/2013 [Citizenship Act], Official Gazette No. 186/2013.

THE CZECH REPUBLIC AND THE REALITY OF MIGRANT INTEGRATION POLICY IN THE CONTEXT OF EUROPEAN INTEGRATION

\section{Summary}

This study has confirmed that the Czech Republic (CR) is an example of a state whose integration and migration policy is very restrictive. Its integration and migration policies have been influenced mainly by migratory flows, economic crises, and European integration. In terms of Europeanisation, it is obvious that the CR carried out fundamental reform in the area of integration and migration policy under the influence of the EU. The implementation of rules in practice bas been inadequate. The Czech Republic has recognised and identified the weaknesses of both policies but has not eliminated these weaknesses in practice. 
The main weakness lies in the fact that both policies are heavily centralised. Local authorities and NGOs do not have sufficient powers and financial resources; moreover, local authorities have no legal obligation to participate in integration. There is a disparity between regions resulting from the unequal concentration of foreigners. A long-term problem is the cultural resistance of society and the requirement for foreigners to assimilate into mainstream society. The migration crisis has increased state activity in the area of migration and integration policy. This is not a manifestation of Europeanisation, but a defence of state interests.

Keywords: Czech Republic; migration policy; integration policy; Europeanisation, migration crisis

\section{REPUBLIKA ČEŠKA I STVARNOST POLITIKE INTEGRACIJE MIGRANATA U KONKTEKSTU EUROPSKIH INTEGRACIJA}

\section{Sažetak}

Republika Češka je zemlja vrlo restriktivne integracijske i migracijske politike. $\mathrm{Na}$ njezine su integracijske i migracijske politike najviše utjecali migracijski tokovi, ekonomske krize i europske integracije. Iz perspektive europeizacije, jasno je da je Češka provela korjenitu reformu u području integracijske i migracijske politike pod utjecajem Europske unije, no na terenu se provedba pokazala neadekvatnom. Iako je Češka prepoznala nedostatke obiju politika, nije ib uklonila u praksi. Glavni je nedostatak taj što su obje politike iznimno centralizirane. Lokalne vlasti i nevladine organizacije nemaju ni ovlasti ni financijskib sredstava, a ne postoji ni zakonska obveza koja bi ib primorala na sudjelovanje u integracijskim aktivnostima. Neravnomjerna gravitacija stranib državljana pojedinim regijama dovela je do nejednakosti medu njima. Dugovječan je problem $i$ otpor društva iz kulturološke perspektive te potreba da se strance asimilira u većinsko društvo. Migrantska kriza pojačala je aktivnosti države u području integracijske i migracijske politike, no u ovom se slučaju ne radi o europeizaciji već o zaštiti državnib interesa.

Ključne riječi: Češka Republika; migracijska politika; integracijska politika; europeizacija; migrantska kriza 